\title{
Model Scheduling Optimization Workforce Management Marketing
}

\author{
Untung Rahardja ${ }^{1}$, Fitri Andriyani ${ }^{2}$, Triyono ${ }^{3}$ \\ 1,2,3STMIK Raharja, Jl. Jenderal Sudirman No. 40 Modern Cikokol, Tangerang \\ e-mail: untung@raharja.info, fitri.andriyani@raharja.info,triyono@raharja.info
}

\section{To cite this document:}

Rahardja, U., Andriyani, F., \& Triyono (2020). Model Scheduling Optimization Workforce Management Marketing. Aptisi Transactions On Management (ATM), 4(2), 92-100.

\section{DOI:}

https://doi.org/10.33050/atm.v4i2.1259

\begin{abstract}
This research focuses on completing workforce management marketing scheduling using genetic metaheuristic methods. Optimal scheduling to determine the duration of a job, the quality of employees, and meet the challenges to increase work scheduling targets according to marketing employee skills by maximizing operational time while providing satisfactory services to customers. Marketing employees increasingly rely on the right time to connect with their customers. The problem in this study considers marketing skills and activities to carry out work activities, namely promotion, follow-up, and stand-by in the office with the limitations of the existing workforce. This problem has the nature of NP-Hard so a quick solution requires the use of metaheuristic methods. The metaheuristic method was built in 11 constraints. The results show that the genetic metaheuristic method is capable of producing far better results. Therefore, employee scheduling is very important. This study aims to develop an optimization model for employee scheduling and to maximize operational time work. With this model, it is expected to achieve optimal scheduling for marketing management workforce.
\end{abstract}

Keywords: Workforce Management, Marketing, Genetic Metaheuristic Methods

\section{Introduction}

The Problem of Scheduling and Routing problems is described as assigning personnel to visits that are requested at various promotional locations, follow up and stand by. This problem focuses on combining scheduling and routing problems [1]. Such problems are NP- hard [2,3] When there are tens or hundreds of employees, with hundreds or thousands of employees shifting that require employee allocation, work activities come from solutions that emerge [4]. Limited resources can be one of the most common problems for corporate development globally. With so many promotional activities and work in the office, so far research has been carried out to create an optimal schedule of activities so that some realistic constraints such as limited resources [5]. In roster settings, when workers do not work shifts that meet their preferences and skills are related to loss of efficiency. Maybe there are no shifts that match the employee (either because of skill requirements or shift start time, etc.) or there may be no employees that match this shift (the same, there are no employees with the right skills or no employees that allow allocation for this change, etc). To reduce the size of the search space, this has traditionally been seen as two different problems and resolved independently. In the 
proposed implementation, the two problems in creating shifts and allocation of employees are solved simultaneously [6-8]. While this increases the complexity of the problem, a combined search space can allow higher quality results to be obtained in Workforce Management (WFM) scheduling [9]. This problem assumes that each resource will be able to be allocated to have several skills.

In this paper focuses on expanding the problem of scheduling the multi-skill marketing Workforce Management (WFM) by learning to consider the efficiency of the workforce involved in performing various skills. This issue has caught the attention of researchers in recent years.

In marketing, each activity requires several skills, each skill can be carried out by different human resources and each person has the ability to perform several skills. In addition, the performance or efficiency of the workforce in carrying out various skills activities can increase from time to time [5]. For this purpose, a genetic algorithm metaheuristic formulation is proposed for marketing scheduling problems. The main objective of the model presented in this paper is to minimize the forefront of work activities. The main advantage of this model is to take the main real assumptions and bring the model closer to the real conditions. Thus, genetic optimization based on metaheuristic algorithms is developed to approach the optimal solution of the model.

Optimization is a method of mathematical approach that aims to obtain maximum operational time objectives. There are a variety of methods that can be used to optimize, but for these cases, more modern techniques such as genetic metaheuristic algorithm [1,10-12] methods are needed. The metaheuristic method is known as a method that is able to solve complex problems quickly [13]. Metaheuristics is an optimization tool to solve this problem. Metaheuristic algorithms find solutions by combining the interaction between local search procedures and higher strategies to create processes that are able to get out of optimal local points and search in the solution space to find global solutions.

Optimal Workforce Management (WFM) scheduling specifically related to performance research is what is most needed, in this study conducted to prove that optimal scheduling can improve the quality of research performance can be realized [14]. They must ensure that these marketing service resources are optimally aligned with the stability of their core work [15]. Utilizing technology and innovation strategies to help and increase the workforce and maximize work in accordance with the skills. This era brings new responsibilities for employees to balance competitive changes in the workplace [16]. The results show that the proposed method can identify this problem.

\section{Research Method}

The data was obtained by conducting direct discussions with marketing leaders at University. Based on the results of the discussion obtained history data for 2017-2018 new student admissions, promotion activity data during 2018, Work Shifts, types of marketing work activities, number of marketing staff available at University and 3 routine marketing activities consisting of promotional activities, follow-up and stand by. The data will be further developed as experimental data in this study.

The optimization process is done with the help of a computer. Computers can optimize if the case they have can be modeled according to the language understood by the computer. Some components need to be prepared before the process of change can be constrained, entity/subject optimization and some data is processed to consider the decisions taken. Constraints from conceptual models are converted into mathematical notation. To be able to convert into variables or parameters, as well as several entities involved such as various activities of work activities, work hours, employees and some models tested are formed as an index. These stages can be seen in Figure 1, Below. 


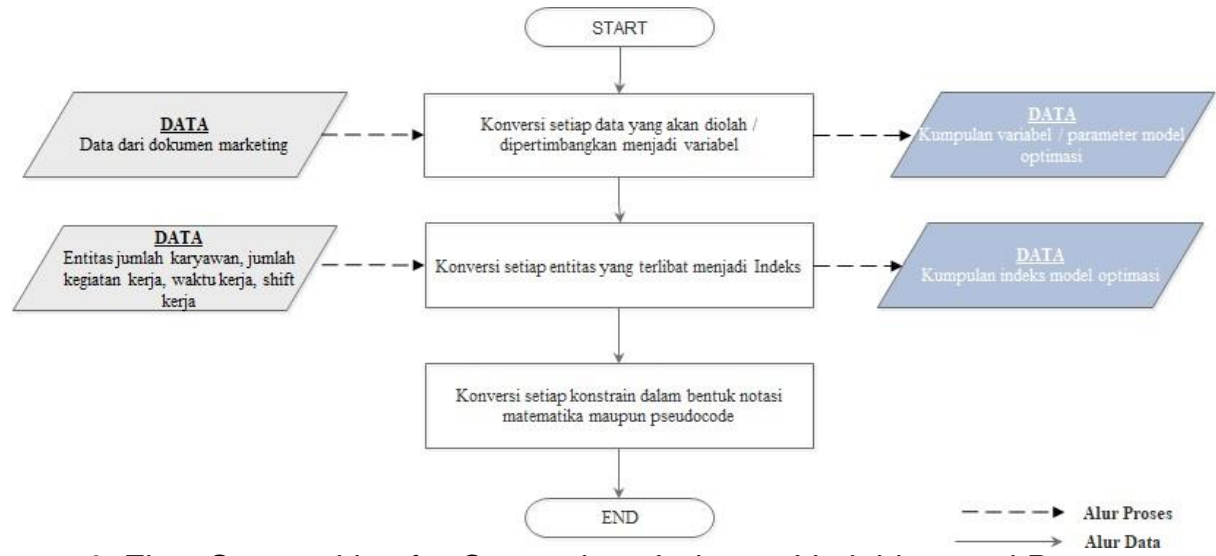

Figure 1. Flow Composition for Constraints, Indexes, Variables, and Parameters

In the optimization of Workforce Management Marketing, there are several constraints that must be resolved. Every employee has the same work duration (40 hours/week) and scheduling is carried out for 24 days/month.

$$
\operatorname{MaxZ}=\sum_{\mathrm{i}=1}^{3}=\sum_{\mathrm{j}=1}^{7}=\sum_{\mathrm{k}=1}^{24}=\sum_{\mathrm{p}=1}^{24} \mathrm{X}_{\mathrm{ijkp}}
$$

Retrieve data from i jobs, employees, hours of work, and workdays and retrieve data from them according to work needs and employee preferences. Genetic metaheuristic algorithms will continue to function.maximize operational time.

Notasi

\section{Parameters}

$\mathrm{i}=\mathrm{Job}$ (1, promotion activity, 2 , stand by 3 , follow up)

$\mathrm{j}=$ Employees $(1,2,3, \ldots, 7)$

$\mathrm{k}=$ Hours $(1=00: 00-01: 00,2=01: 00-02: 00, \ldots, 24=23: 00-24: 00)$

$\mathrm{p}=$ Day (date) $(1,2,3, \ldots 24) \rightarrow$ Monday - Saturday

$\mathrm{n}=$ Student assistance promotion $(1,2, \ldots, 10)$

Decision variables

$Q_{p}=$ Number of prospective new students enrolling in period $p$

$\mathrm{H}_{\mathrm{kp}}=$ The number of people needed for the promotion of hours to $k$ in period $p$

$\mathrm{S}_{\mathrm{ij}}=\left\{\begin{array}{l}1, \text { employee } \mathrm{j} \text { can do the work } \mathrm{i} \\ 0 \text {, vice versa }\end{array}\right.$

$\mathrm{X}_{\mathrm{ijkp}}=\left\{\begin{array}{l}1, \text { if employee } \mathrm{j} \text { works at work } \mathrm{i} \text { at hour } \mathrm{k} \text { on day } \mathrm{p} \text { and } \mathrm{S}_{\mathrm{ij}}=1 \\ 0 \text {, vice versa }\end{array}\right.$

$\mathrm{M}_{\mathrm{nkp}}=\left\{\begin{array}{l}1, \text { If a student participates in promotional activities at } \mathrm{k} \text { hours on day } \mathrm{p} \\ 0, \text { vice versa }\end{array}\right.$

2) Managers (employees 1) must be on stand by at 08:00 - 17:00 Monday - Friday.

$$
\begin{aligned}
& \mathrm{X}_{21 \mathrm{kp}}=1 \quad \mathrm{k} \in\{8,9, \ldots 17\} \\
& \forall \mathrm{p} \backslash\{6,12,18,24\}
\end{aligned}
$$

3) All employees can do stand by work in office. 
4) Employees 2, 3, 4 can do all the work stand by, follow up and Promotion.

$$
\begin{array}{lc}
\mathrm{S}_{2 j}=1 & \forall j \\
\sum_{\mathrm{i}=1}^{3} \mathrm{~S}_{i j}=3 & j \in\{2,3,4\}
\end{array}
$$

5) Working hours 40 hours/week or 160 hours/month for every employee .

$$
\sum_{\mathrm{p}=1 \mathrm{k}=1 \mathrm{i}=1}^{24} \sum_{\mathrm{ijkp}}^{3}
$$

6) Working hours per day (Monday-Friday) every employee shifts 08:00 - 17:00 can be 7 hours or more, with many employees 5 people.

7) Working hours per day (Monday - Friday) each employee shift 12:00 - 21:00 can be 7 people or more, with many employees 2 people.

8) Working hours Saturday shift 09:00 - 14: 00 can be 5 hours or more with many employees 1 person.

$$
\begin{aligned}
& \sum_{\mathrm{j}=1 \mathrm{i}=1 \mathrm{k}=8}^{3} \sum_{\mathrm{k}=8}^{17} \mathrm{x}_{\mathrm{ijkp}} \geq(5 \mathrm{X} 7) \quad \forall \mathrm{P}\{66,12,18,24\} \\
& \sum_{\mathrm{j}=1 \mathrm{i}=1 \mathrm{k}=12}^{7} \sum_{\mathrm{k}=1 \mathrm{j}}^{21} \mathrm{X}_{\mathrm{ijk}} \geq(2 \mathrm{X} 7) \quad \forall \mathrm{P} \backslash\{6,12,18,24\} \\
& \sum_{j=1 \mathrm{i}=1 \mathrm{k}=9}^{7} \sum_{\mathrm{ijkp}}^{14} \mathrm{X}_{\mathrm{j}} \geq 5 \quad \mathrm{P} \in\{6,12,18,24\}
\end{aligned}
$$

9) Employees who take part in promotional activities are a maximum of 2 people.

$$
\sum_{j=1}^{7} x_{1 j k p} \leq 2 \quad \forall k, \forall p
$$

10) There are at least 2 people in the office on stand by / follow up

$$
\begin{aligned}
\sum_{j=1}^{7} X_{1 j k p} \geq 2 & \forall k \\
& i \in\{2,3\} \\
& p \in \backslash\{, 12,18,24\}
\end{aligned}
$$

11) Promotional activities $i$ are filled with a maximum of 2 staff and the rest are students assistance at hour $\mathrm{k} \mathrm{p}$.

$$
\sum_{\mathrm{j}=1}^{7}=1 \mathrm{X}_{1 \mathrm{jkp}}+\sum_{\mathrm{n}=1}^{10}=1 \mathrm{M}_{\mathrm{nkp}}=\mathrm{H}_{\mathrm{kp}} \quad \forall \mathrm{k}, \forall \mathrm{p}
$$

\section{Results and Analysis}

By recording constraint genetic algorithm scheduling produces optimal schedules with metaheuristic methods web-based applications are arranged based on constraints.

The interface for the login page can be seen in Figure 2. In this section, Kabiro and employees will be asked to fill in their username and password to access the main menu. 


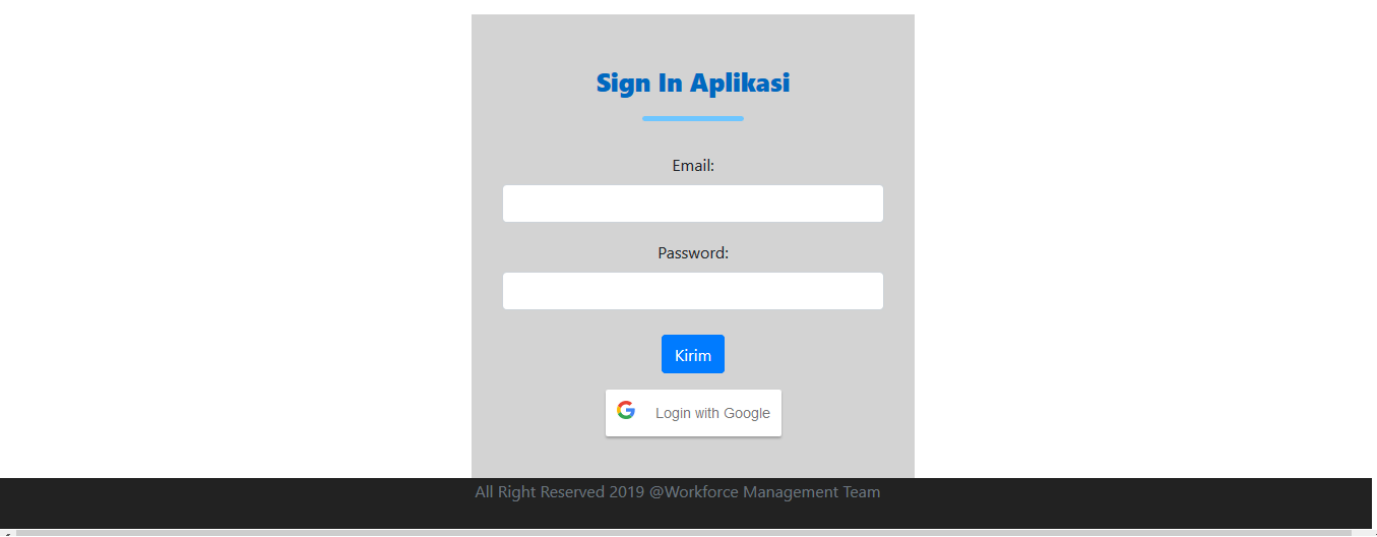

Figure 2. Tampilan Halaman login

Figure 3 is a List of marketing employees. This page contains employee data recorded as marketing employees. In this section, there is a display showing information about the detailed information of each employee's name, email, position, status, address, place \& date of birth, gender, user login, date of joining in marketing and resign date.
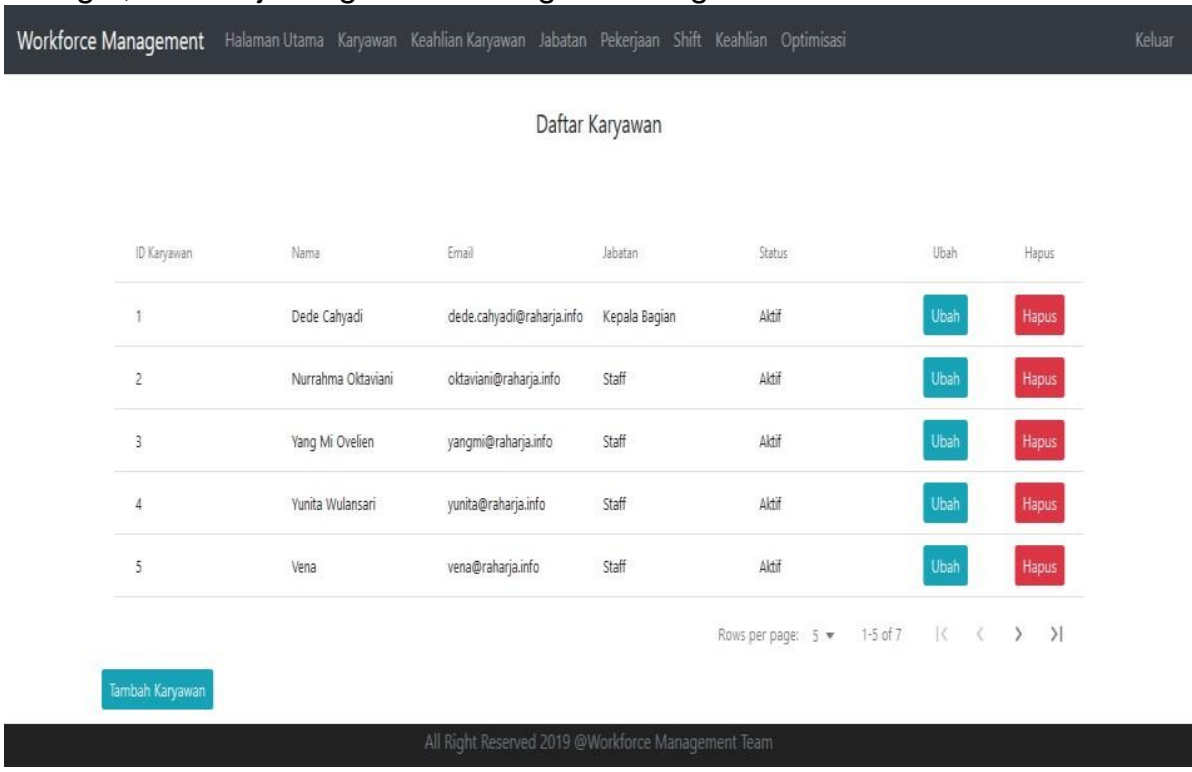

Figure 3. Display list of marketing employees

Figure 4, Display the list of Employee Skills. This page contains skills data for each employee that combines employee and expertise tables. In this section, there is a display showing information about employee IDs and expertise. 
Daftar Keahlian Karyawan

\begin{tabular}{|c|c|c|}
\hline Nama & Keshlian & Ubah \\
\hline Dede Cahyadi & Stand By & Ubah \\
\hline Nurrahma Olataviani & Follow Up & Ubah \\
\hline Nurrahma Oltaviani & Promosi & Ubah \\
\hline Nurrahma Otaviani & Stand by & Ubah \\
\hline Vang Mi ovelien & Follow Up & Ubah \\
\hline
\end{tabular}

Figure 4. Display list of Employee Skills

Figure 5, Display the Position list. This page contains the position data of each employee to determine the login role as well as to access according to the role title In this section there is a display showing information about the position code and the name of the position.

Workforce Management Halaman Utama Karyawan Keahlian Karyawan Jabatan Pekerjaan Shift Keahlian Optimisasi

Daftar Jabatan

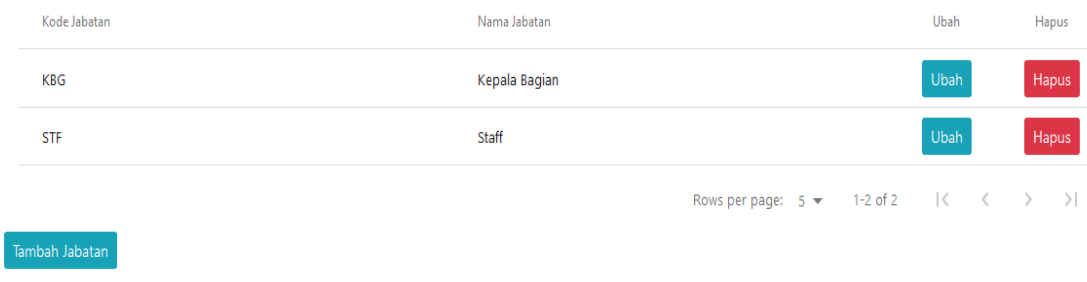

Figure 5. Display the position list

Figure 6, Job list display. This page displays the results of optimization that have been assigned to related employees and jobs that have not yet been assigned. So that it can import work so that optimization can save directly on the job list which consists of work code, job description, shift, date, start time and end time. 
Daftar Pekerjaan

\begin{tabular}{|c|c|c|c|c|c|c|c|c|c|}
\hline Kode Pekerjan & Deskripsi Pekerjaan & Shirt & Tanggal & Iam Mulai & Jam Selesai & & Ubah & & Hapus \\
\hline $\mathrm{Fu}$ & Follow Up & sp & 2019-12-07 & 09:00:00 & 12:00:00 & & Ubah & & Hapus \\
\hline $\mathrm{FU}$ & Follow Up & sS & 2019-12-07 & 13:00:00 & 17:00:00 & & Ubah & & Hapus \\
\hline p & Promosi & sp & 2019-12-07 & 09:00:00 & 12:00:00 & & Ubah & & Hapus \\
\hline ST & Stand By & SP & 2019-12-07 & 08:00:00 & 17:00:00 & & Ubah & & Hapus \\
\hline \multirow[t]{2}{*}{ ST } & Stand by & ss & 2019-12-07 & 12:00:00 & 21:00:00 & & Ubah & & Hapus \\
\hline & & & & & age: 5 & $1-5$ of 5 & k & r & >। \\
\hline
\end{tabular}

Figure 6. Job list display

Figure 7, Display shift list. This page contains shift data for each employee consisting of 3 (three) shifts for 6 (six) working days. In this section there is a display showing information about the shift code, shift names, start hours and hours after work.

Workforce Management Halaman Utama Karyawan Keahlian Karyawan Jabatan Pekerjaan Shift Keahlian Optimisasi

\begin{tabular}{|c|c|c|c|c|c|}
\hline Kode Shift & Nems Shitt & Jam Mulai & Jam Selessi & Ubah & Hapus \\
\hline$S P$ & Shitt Pagi & 08:00:00 & $17: 00: 00$ & Ubah & Hapus \\
\hline ss & Shit Siang & 12:00:00 & $21: 00: 00$ & Ubah & Hapus \\
\hline SB & Shit sabtu & 09:00:00 & $14: 00: 00$ & Ubah & Hapus \\
\hline
\end{tabular}

Figure 7. Display shift list

Figure 8, Display Expertise list. This page contains the expertise data of each employee. In this section, there is a display showing information about the expertise code and the name of the work expertise. 
Workforce Management Halaman Utama Karyawan Keahlian Karyawan Jabatan Pekerjaan Shift Keahlian Optimisasi

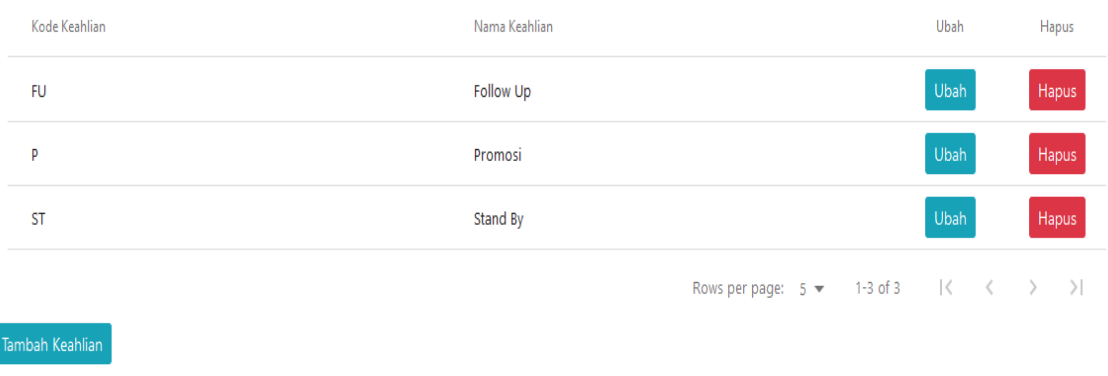

Figure 8. Display the Expertise list

Figure 9, Display Optimization. On this page, there is an optimization page. Optimization is processed based on employee data, employee expertise, position, work, and work shifts with constraints that have been made and produce optimal scheduling that displays the total work of each employee in one month.

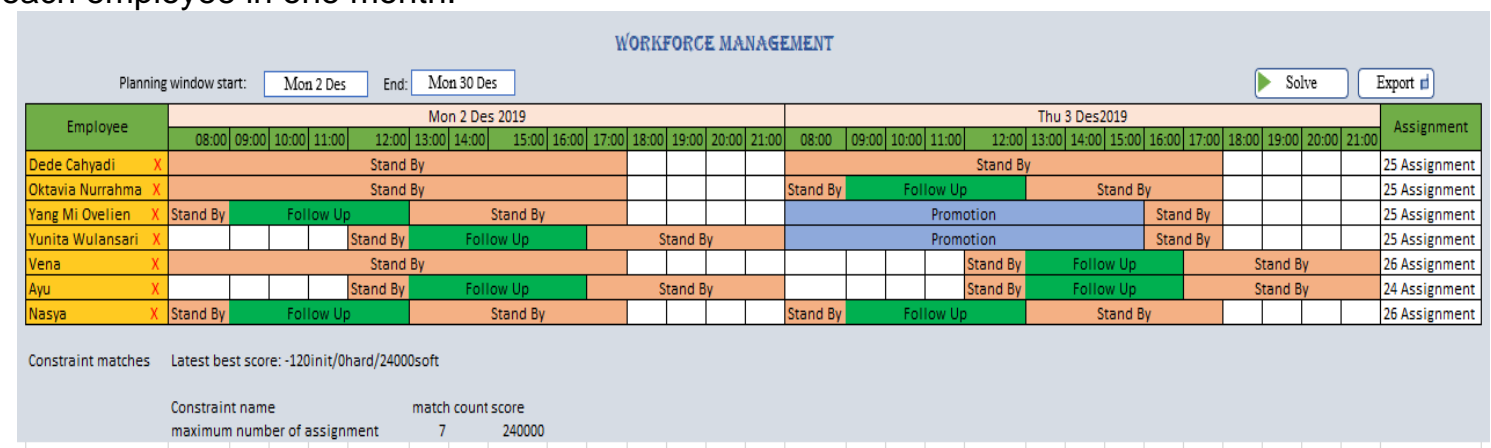

Figure 9. Display schedule optimization

\section{Conclusion}

In this research, we have studied the problem of identifying optimal workforce management scheduling for marketing services. This analysis aims to:

1. This research proposes web-based solves the problem of scheduling employee preferences and the problem of staff allocation for various activities in marketing services.

2 The decision model includes the goal of obtaining skill efficiency, development cycle and operational time in accordance with work shifts.

3. Programming models with genetic metaheuristics are formulated to model decision problems that are designed to solve models with many marketing work activities. In this algorithm, Metaheuristic Genetics is used to produce a schedule to optimize the division of employee work and staff skills calculated in the process. 


\section{References}

[1] Algethami, H., \& Landa-Silva, D. (2017, June). Diversity-based adaptive genetic algorithm for a Workforce Scheduling and Routing Problem. In 2017 IEEE Congress on Evolutionary Computation (CEC) (pp. 1771-1778). IEEE.

[2] Pinedo, M., Zacharias, C., \& Zhu, N. (2015). Scheduling in the service industries: An overview. Journal of systems science and systems engineering, 24(1), 1-48.

[3] Molnar, G., Jakobović, D., \& Pavelić, M. (2016, March). Workforce Scheduling in Inbound Customer Call Centres with a Case Study. In European Conference on the Applications of Evolutionary Computation (pp. 831-846). Springer, Cham.

[4] Reid, K. N., Li, J., Swan, J., McCormick, A., \& Owusu, G. (2016, December). Variable neighbourhood search: A case study for a highly-constrained workforce scheduling problem. In 2016 IEEE Symposium Series on Computational Intelligence (SSCI) (pp. 1-6). IEEE.

[5] Zabihi, S., Kahag, M. R., Maghsoudlou, H., \& Afshar-Nadjafi, B. (2019). Multi-objective teachinglearning-based meta-heuristic algorithms to solve multi-skilled project scheduling problem. Computers \& Industrial Engineering, 136, 195-211.

[6] Seada, A. A., \& Eltawil, A. B. (2015, March). Modeling and analysis of workforce management decisions in modern call centers. In 2015 International Conference on Industrial Engineering and Operations Management (IEOM) (pp. 1-10). IEEE.

[7] Ang, B. Y., Lam, S. W. S., Pasupathy, Y., \& Ong, M. E. H. (2018). Nurse workforce scheduling in the emergency department: A sequential decision support system considering multiple objectives. Journal of nursing management, 26(4), 432-441.

[8] Gans, N., Shen, H., Zhou, Y. P., Korolev, N., McCord, A., \& Ristock, H. (2015). Parametric forecasting and stochastic programming models for call-center workforce scheduling. Manufacturing \& Service Operations Management, 17(4), 571-588.

[9] Reid, K. N., Li, J., Veerapen, N., Swan, J., McCormick, A., Kern, M., \& Owusu, G. (2018, September). Shift Scheduling and Employee Rostering: An Evolutionary Ruin \& Stochastic Recreate Solution. In 2018 10th Computer Science and Electronic Engineering (CEEC) (pp. 1923). IEEE.

[10] Moschakis, I. A., \& Karatza, H. D. (2015). A meta-heuristic optimization approach to the scheduling of bag-of-tasks applications on heterogeneous clouds with multi-level arrivals and critical jobs. Simulation Modelling Practice and Theory, 57, 1-25.

[11] Diveev, A. I., \& Bobr, O. V. (2017). Variational genetic algorithm for $n p$-hard scheduling problem solution. Procedia Computer Science, 103, 52-58.

[12] Shishido, H. Y., Estrella, J. C., Toledo, C. F. M., \& Arantes, M. S. (2018). Genetic-based algorithms applied to a workflow scheduling algorithm with security and deadline constraints in clouds. Computers \& Electrical Engineering, 69, 378-394.

[13] Torres-Jiménez, J., \& Pavón, J. (2014). Applications of metaheuristics in real-life problems.

[14] Rahardja, U., Hariguna, T., \& Baihaqi, W.M. (2019). OPINION MINING ON E-COMMERCE DATA USING SENTIMENT ANALYSIS AND K-MEDOID CLUSTERING. 2019 Twelfth International Conference on Ubi-Media Computing (Ubi-Media), 168-170.

[15] Aini, Q., Rahardja, U., \& Hariguna, T.(2019). The antecedent of perceived value to determine of student Continuance Intention and student Participate Adoption of iLearning. The Fifth Information Systems International Conference 2019, 1-8.

[16] Rahardja, U. (2009, May). Artificial informatics. In 2009 4th IEEE Conference on Industrial Electronics and Applications (pp. 3064-3067). IEEE. 